\title{
Leaf emergence and tillering in barley and wheat
}

\author{
E. J. M. KIRBY, Margaret APPLEYARD \& Gwynneth FELLOWES
}

Plant Breeding Institute, Trumpington, Cambridge CB2 $2 L Q, U K$

\begin{abstract}
A scheme to relate leaf emergence and tillering is described. It assumes that $\mathbf{3}$ phyllochrons elapse between the emergence of a leaf and the tiller in its axil (phyllochron interval) and that leaves emerge at the same rate on all shoots. These assumptions were examined in several varieties of wheat and barley sown on 4 different dates in each of 3 seasons. It was found that the phyllochron interval was generally about 3 but that it tended to be longer in the coleoptile tillers and the 1st secondary tiller. There were significant differences in the rate of leaf emergence amongst shoots. In spite of these considerations observed tiller production measured on a main shoot leaf number basis agreed well with the predicted production. The main shoot leaf number at which tillering ceased was correlated with total number of leaves on the main shoot. These results indicate that rate of tillering will vary with rate of leaf production and that genetic variation in rate of leaf production may be used to predict and select for different tillering patterns.
\end{abstract}

Additional key words : Phyllochron interval, cessation of tillering.

\begin{abstract}
Apparition des feuilles et des talles chez l'orge et le blé.
Nous décrivons ici un schéma pour établir un rapport entre apparition des feuilles et apparition des talles. Le schèma suppose que 3 phyllochrones séparent l'apparition d'une feuille de celle de la talle qu'elle engaine ('phyllochrone interval') et que les feuilles apparaissent au même rythme sur tous les brins. La réalité de ces comportements a été examinée au champ pour des peuplements de blé et d'orge pour 4 dates de semis et 3 années. On constate que le 'phyllochrone interval' est en général d'environ 3, mais qu'il tend à être plus long pour les talles de coléoptile et la première talle secondaire. Les vitesses d'apparition des feuilles varient entre brins. Malgré ces considérations, la production observée est en bon accord aveç le nombre de brins prédit par le modèle compte tenu du nombre de feuilles du brin-maître. Le nombre de feuilles sur le brin-maître au moment de l'arrêt du tallage est corrélé avec son nombre total de feuilles. Ces résultats indiquent que la vitesse de tallage dépend de la vitesse d'initiation des feuilles. Les variations liées au génotype peuvent être prises en compte pour la sélection de génotypes avec différents rythmes d'apparition des talles.
\end{abstract}

Mots clés additionnels : Phyllochrone, arrêt du tallage.

\section{INTRODUCTION}

The time and rate at which tillers are produced is important to several aspects of plant breeding and agronomy. These components have been carefully researched on a crop basis (e.g. INNES et al., 1981 ; DARWINKEL, 1978, in relation to genotype and plant population respectively). Such studies, while giving much information about tillering on a unit area basis, do not relate it to other plant parameters. Analyses of tillering on a plant basis may be more revealing of the factors involved and are important in crop models where leaf area is simulated on a plant basis.

The relationship between tillering and leaf emergence has been realised for a long time, for example ENGLEDOW \& RAMIAH (1930) noted a relationship be- tween rate of leaf emergence and rate of tillering amongst different varieties of wheat. A comprehensive theoretical analysis of leaf emergence and tiller production was made by FRIEND (1965). He proposed that there was a constant 'leaf interval' between the emergence of a leaf and the emergence of the tiller in its axil. $\mathrm{He}$ showed that if the rate of leaf emergence on the main shoot and the tillers was constant then the total number of shoots and number of leaves per plant increased in a Fibonacci series. Similar analyses of leaf emergence and tillering have been made in wheat by MASLE-MeYNARD \& SebillotTE (1981) and by KLEPPER et al. (1982).

It has been proposed that this form of analysis can be the basis for both the prediction of numbers of leaves and tillers and for the identification of stress factors 
which cause tillering to cease completely or temporarily (MASLE-MEYNARD \& SEBILlOTTE, 1981 ; KLEPPER et al., 1982). In this paper we test the 2 rules which are assumed in the analysis. These are

1. The rate of leaf emergence is the same in the main shoot and tillers.

2. The interval between the emergence of a leaf and the tiller in its axil is constant.

We also analyse the cessation of tillering in relation to emergence of leaves. The analysis was made on barley and wheat in experiments in which a number of varieties were grown over 4 seasons at a number of sowing dates and in which main shoot leaf emergence rate was shown to be affected by sowing date and variety (KIRBY et al., 1985).

\section{MATERIALS AND METHODS}

\section{A. Experimental details}

The details of the experimental design and site, the varieties used and the dates upon which the experiments were sown are given in the previous paper (KIRBY et al., 1985). Briefly, the experiment was conducted in two years with barley $(1979 / 80,1980 / 81)$ and wheat $(1980 / 81,1981 / 82)$. In each year there were 4 sowing dates, mid-September (sowing 1), midOctober (2), mid-November (3) and mid-February (4). Nine genotypes of each species were grown, mostly commercial winter varieties, but also including advanced breeding lines and spring varieties.

\section{B. Leaf emergence}

Samples were taken once or twice a week, depending on temperature and for each sample tillers were identified according to the convention described by KIRBY \& APPLEYARD (1981). The primary tillers are identified by the structure with which they are associated e.g. TC (the tiller in the axil of the coleoptile), T1 (the tiller in the axil of leaf 1, etc.). Similarly with the higher order tillers, thus T1P is a secondary tiller, borne in the axil of the prophyll of T1. The number of leaves on the main shoot (MS) and each of the tillers was counted. A leaf was defined as having emerged when its tip could be seen above the level of the uppermost auricles of the previous leaves. A tiller was said to have emerged when its first leaf was visible above the ligule of the subtending leaf.

\section{Phyllochron interval}

The interval between the emergence of the leaf and its subtended tiller is measured in this paper in terms of phyllochrons and is called the 'phyllochron interval'. A phyllochron is the interval between the emergence of one leaf and the next and has the units of time or degree days $\left({ }^{\circ} \mathrm{Cd}\right)$ where accumulated temperature is used. The reciprocal of the phyllochron is the rate of leaf emergence. The term phyllochron interval has been more used in recent papers (KLEPPER et al., 1982) but is comparable with the 'leaf interval' defined by FRIEND (1965).

\section{Estimation of the phyllochron interval}

Two methods have been used to estimate the phyllochron interval. In the first, the mean number of leaves on the main shoot when a tiller had one leaf was calculated. This was done by taking the mean number of leaves on the main shoot of all those plants which, when sampled, had one leaf on the specified tiller (between 60 and 100 plants for each estimation). For example, in the case of 'Norman' winter wheat, sowing $21981 / 82$, plants with only the first leaf emerged on T1 were measured during the period from 5 until 26 January. Of these plants $10 \%$ had three leaves on the main shoot and $90 \%$ had four leaves giving a mean of 3.9 leaves on the main shoot. The phyllochron interval was derived from the number of emerged leaves on the main shoot minus the leaf number of the main shoot at which the tiller emerged i.e. if T1 appears when there are four leaves on the main shoot the phyllochron interval is 3 . In this paper the estimate was based on destructive sampling, not on repeated measurements of the same plant and no estimate was made of parts of leaves emerged - a leaf was either emerged or not (cf. the system of counting leaves of HAUN, 1973). The second method is based on regression. The number of leaves on a shoot was a linear function of accumulated temperature (fig. 1). Therefore the accumulated temperature when, for example, tiller 1 had one leaf could be estimated by linear regression. This estimate could then be entered into the regression equation for the main shoot to calculate the number of leaves at the estimated emergence time of the tiller.

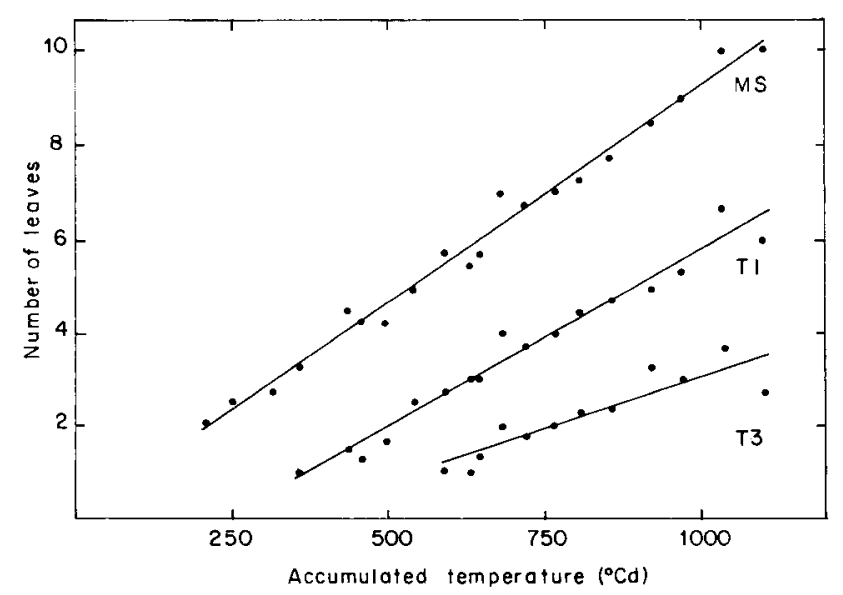

Figure 1

Number of leaves on the main shoot, $T 1$ and $T 3 v$. accumulated temperature from date of sowing for 'Huntsman' winter wheat 1981/82, sowing 2. (For clarity the data for T2 was omitted.)

Nombre de feuilles sur le brin-maître, Tl et T3 en fonction de la température accumulée depuis le semis pour le blé d'hiver « Huntsman $", 2^{e}$ semis. (Pour raison de clarté, les données pour T2 ont été omises.)

\section{RESULTS}

\section{A. Rate of tiller leaf emergence}

When, for each variety, the number of leaves on each shoot was plotted against accumulated tempera- 
ture the rate of leaf emergence for each shoot in wheat and barley was constant for most sowings and there was no systematic deviation from the line fitted by linear regression (fig. 1).

The rate of leaf emergence of the main shoot and the tillers was estimated by linear regression of number of leaves against accumulated temperature, as described in the previous paper for main shoots only (KIRBY et al., 1985). The base temperature used for estimation of accumulated temperature was $0{ }^{\circ} \mathrm{C}$ for wheat and $1{ }^{\circ} \mathrm{C}$ for barley.

Comparison of the rates estimated by linear regression showed that there were significant differences between varieties and sowings which were discussed in the previous paper (KIRBY et al., 1985). There were differences amongst shoots, which analysis of variance of the rates for the MS, T1 and T2 showed to be significant over all shoots (barley, 1980/81, VR $=328$, $\mathrm{P}<0.001$; wheat, $1980 / 81$, VR $=521, \mathrm{P}<0.001)$. The relationship between the rate of leaf emergence on the main shoot and tillers was little affected by variety (variety $\times$ shoot interaction for barley $\mathrm{VR}=1.74$, $\mathrm{P}<0.05$; and for wheat $\mathrm{VR}=1.56, \mathrm{P}<0.05)$ and mean rate for each shoot over all varieties is shown in table 1 . The rates of leaf emergence of the tillers were lower than that of the main shoot. In sowings 1 to 3 the rates of $\mathrm{T} 1$ and $\mathrm{T} 2$ were about $85 \%$ and $80 \%$ respectively, of the main shoot. In sowing 4 the proportional differences were greater and rates were about $70 \%$ for $\mathrm{T} 1$ and $63 \%$ for $\mathrm{T} 2$. The analysis of variance of rate of leaf emergence for the main shoot, T1 and T2 showed that the sowing date $\times$ shoot interaction was significant $(P<0.01)$ in both species.

The trend in leaf emergence rates was generally $\mathrm{MS}>\mathrm{T} 1>\mathrm{T} 2>\mathrm{TC}, \mathrm{T} 3, \mathrm{~T} 1 \mathrm{P}$. In the cases where
TC was produced it emerged at about the same time or slightly before $\mathrm{T} 1$ but its rate was considerably lower. Amongst the later produced tillers the primary tiller T3 had a higher rate than the secondary tiller $\mathrm{T} 1 \mathrm{P}$ which was produced at about the same time.

\section{B. Phyllochron interval}

The frequency distribution of number of leaves present on the main shoot when a tiller had one leaf present indicated that there was little variation in leaf status of the main shoot when the tiller was produced and in most cases more than $75 \%$ of the tillers within a class were produced at a particular leaf number (table 2). The phyllochron interval was about 3 and there was little variation due to species or variety. It tended to be longer for TC, and also tended to increase the later the plant was sown, particularly for the secondary tillers (table 3 ). When estimated by regression the phyllochron interval, over all tillers was on average 1.9 .

\section{Number of tillers $v$, number of main shoot leaves}

If it is assumed that main shoot and tiller leaves emerge at the same rate, and that the phyllochron interval is 3 , then the increase in number of shoots relative to number of leaves follows a Fibonacci series (table 4 and FRIEND, 1965 ; MASLE-MEYNARD \& SEBILLOTTE, 1981). In table 4 the analysis assumes that a coleoptile tiller is produced. Most of the plants in the experiments described in this paper did not produce a coleoptile tiller, therefore the relationship was re-calculated to allow for this. The increase in the number of shoots relative to the number of leaves fol-

TABLE 1

Mean rate of leaf emergence on the main shoot and tillers for each sowing, over all varieties for wheat and barley for two years. Base temperature selected for wheat was $O{ }^{\circ} \mathrm{C}$ and for barley $1{ }^{\circ} \mathrm{C}$. Rates are leaves $\left(100{ }^{\circ} \mathrm{Cd}\right)^{-1}$.

Vitesse moyenne d'apparition des feuilles sur le brin-maître et les talles pour les différentes dates de semis pour toutes les variétés de blé et d'orge et pour 2 années. Température de base retenue pour la sommation des températures: $0{ }^{\circ} \mathrm{C}$ pour le blé, $I^{\circ} \mathrm{C}$ pour l'orge. Les chiffres correspondent au nombre de feuilles produit par 100 degrés-jours.

\begin{tabular}{|c|c|c|c|c|c|c|c|c|}
\hline \multicolumn{9}{|l|}{ Wheat } \\
\hline \multirow[b]{2}{*}{ Shoot } & \multicolumn{4}{|c|}{$1980 / 81$} & \multicolumn{4}{|c|}{$1981 / 82$} \\
\hline & 1 & 2 & 3 & 4 & 1 & 2 & 3 & 4 \\
\hline MS & 0.74 & 0.88 & 1.05 & 1.25 & 0.74 & 0.90 & 1.08 & 1.28 \\
\hline $\mathrm{TC}$ & 0.47 & - & - & - & 0.48 & - & - & - \\
\hline T1 & 0.65 & 0.76 & 0.95 & 0.78 & 0.64 & 0.72 & 0.85 & 1.01 \\
\hline T1P & 0.41 & - & - & - & 0.40 & - & - & - \\
\hline $\mathrm{T} 2$ & 0.59 & 0.75 & 0.89 & 0.77 & 0.59 & 0.63 & 0.75 & 0.98 \\
\hline T3 & 0.48 & 0.49 & - & - & 0.45 & 0.48 & 0.44 & - \\
\hline
\end{tabular}

\begin{tabular}{|c|c|c|c|c|c|c|c|c|}
\hline \multicolumn{9}{|l|}{ Barley } \\
\hline Shoot & 1 & 2 & 3 & 4 & 1 & 2 & 3 & 4 \\
\hline MS & 1.06 & 1.36 & 1.71 & 1.91 & 0.98 & 1.03 & 1.22 & 1.43 \\
\hline $\mathrm{TC}$ & 0.67 & 0.94 & 1.10 & 1.20 & 0.67 & - & - & - \\
\hline $\mathrm{T} 1$ & 0.82 & 1.30 & 1.58 & 1.45 & 0.85 & 0.95 & 1.14 & 0.88 \\
\hline $\mathrm{T} 1 \mathrm{P}$ & 0.64 & 0.73 & 0.84 & 0.52 & 0.59 & 0.58 & 0.43 & - \\
\hline $\mathrm{T} 2$ & 0.75 & 1.20 & 1.41 & 1.20 & 0.78 & 0.95 & 1.02 & 0.73 \\
\hline T3 & 0.74 & 1.08 & 1.09 & 0.80 & 0.72 & 0.85 & 0.80 & - \\
\hline
\end{tabular}


TABLE 2

Number of leaves on the main shoot when each tiller had one emerged leaf. Values are for all varieties and are the number of plants in each leaf class as a percentage of the total number of plants sampled. (Where values do not add up to 100 there are plants outside the listed classes.)

Nombre de feuilles du brin-maitre quand les talles $T 1, T 2$ et $T 3$ avaient une feuille. Les valeurs sont données toutes variétés confondues et représentent les pourcentages de plantes, dans chaque classe de nombre de feuilles, $p$. 100 exprimés par rapport au nombre total de plantes. (Les totaux inférieurs à 100 p. 100 correspondent à des cas où il existait d'autres classes de feuilles pour le brin-maitre.)

\begin{tabular}{|c|c|c|c|c|c|}
\hline $\begin{array}{l}\text { Wheat } 1981 / 82 \\
\text { Tiller }\end{array}$ & $\begin{array}{c}\text { Main shoot } \\
\text { number of leaves }\end{array}$ & 1 & 2 & 3 & 4 \\
\hline $\mathrm{T} 1$ & $\begin{array}{l}3 \\
4 \\
5\end{array}$ & $\begin{array}{r}13 \\
81 \\
3\end{array}$ & $\begin{array}{r}4 \\
92 \\
4\end{array}$ & $\begin{array}{r}-\overline{97} \\
3\end{array}$ & $\begin{array}{l}- \\
83 \\
17\end{array}$ \\
\hline $\mathrm{T} 2$ & $\begin{array}{l}4 \\
5 \\
6\end{array}$ & $\begin{array}{l}34 \\
66 \\
-\end{array}$ & $\begin{array}{r}17 \\
79 \\
3\end{array}$ & $\begin{array}{l}23 \\
75 \\
-\end{array}$ & $\begin{array}{r}- \\
94 \\
3\end{array}$ \\
\hline $\mathrm{T} 3$ & $\begin{array}{l}5 \\
6 \\
7 \\
8\end{array}$ & $\begin{array}{r}18 \\
77 \\
4 \\
-\end{array}$ & $\begin{array}{l}-\overline{85} \\
13 \\
-\end{array}$ & $\begin{array}{r}25 \\
43 \\
8 \\
12\end{array}$ & $\begin{array}{l}13 \\
74 \\
10 \\
-\end{array}$ \\
\hline
\end{tabular}

\begin{tabular}{|c|c|c|c|c|c|}
\hline $\begin{array}{l}\text { Barley } 1980 / 81 \\
\text { Tiller }\end{array}$ & $\begin{array}{c}\text { Main shoot } \\
\text { number of leaves }\end{array}$ & 1 & 2 & 3 & 4 \\
\hline $\mathrm{T} 1$ & $\begin{array}{l}3 \\
4 \\
5 \\
6\end{array}$ & $\begin{array}{r}15 \\
81 \\
3 \\
1\end{array}$ & $\begin{array}{r}7 \\
73 \\
12 \\
5\end{array}$ & $\begin{array}{r}3 \\
91 \\
6 \\
-\end{array}$ & $\begin{array}{r}7 \\
62 \\
17 \\
7\end{array}$ \\
\hline $\mathrm{T} 2$ & $\begin{array}{l}4 \\
5 \\
6\end{array}$ & $\begin{array}{r}19 \\
79 \\
1\end{array}$ & $\begin{array}{r}15 \\
82 \\
3\end{array}$ & $\begin{array}{r}31 \\
67 \\
2\end{array}$ & $\begin{array}{r}13 \\
68 \\
9\end{array}$ \\
\hline T3 & $\begin{array}{l}5 \\
6 \\
7 \\
8\end{array}$ & $\begin{array}{r}6 \\
86 \\
7 \\
-\end{array}$ & $\begin{array}{r}7 \\
93 \\
-\end{array}$ & $\begin{array}{r}15 \\
73 \\
6 \\
4\end{array}$ & $\begin{array}{r}3 \\
59 \\
9 \\
15\end{array}$ \\
\hline
\end{tabular}

TABLE 3

Phyllochron interval for tillers of wheat and barley in 1980/81. Mean over all varieties, calculated by 'first' method (see text).

Valeur du 'phyllochrone interval' pour différentes talles chez le blé et l'orge (1980/81). Moyenne toutes variétés confondues, calculée par la lre méthode (voir texte).

\begin{tabular}{lcccc}
\hline \hline Wheat & \multicolumn{4}{c}{ Sowing } \\
Tiller & 1 & 2 & 3 & 4 \\
\hline TC & 5.1 & 3.5 & 4.1 & - \\
T1 & 2.9 & 2.9 & 3.0 & 3.2 \\
T1P & 2.4 & 3.0 & 3.2 & 3.5 \\
T2 & 2.7 & 2.7 & 2.5 & 3.0 \\
T3 & 2.8 & 2.8 & 3.0 & 3.2 \\
\hline
\end{tabular}

\begin{tabular}{lcccc}
\hline Barley & \multicolumn{4}{c}{ Sowing } \\
Tiller & 1 & 2 & 3 & 4 \\
\hline TC & 4.6 & 4.7 & 5.6 & 4.0 \\
T1 & 2.9 & 3.2 & 3.0 & 3.5 \\
T1P & 2.9 & 3.3 & 3.7 & 4.0 \\
T2 & 2.9 & 2.9 & 2.7 & 3.3 \\
T3 & 3.0 & 2.9 & 3.1 & 3.8 \\
\hline
\end{tabular}

lows the same Fibonacci series but offset by one leaf i.e. when leaf 4 on the main shoot emerges there are two shoots ( 11 and MS), three shoots at leaf 5, five shoots at leaf 6 , etc. Using this relationship observed tiller production was compared with the potential or theoretical tiller production.

This was done for each variety for all sowing dates by plotting the theoretical and observed number of shoots per plant $v$. number of leaves on the main shoot (e.g. 'Huntsman' winter wheat 1981/82 ; 'Sonja' winter barley and 'Ark Royal' spring barley 1980/81, fig. 2). Over the first six or eight leaves there was good agreement between the theoretical and observed values, and any deviation appeared to be due mainly to variation in the production of the coleoptile tiller which appeared in a few plants, particularly in sowing 1. Such variation in the production of TC is common (CANNELL, 1969 ; RAWSON, 1971).

At some point (e.g. 'Huntsman' sowing 4, fig. 2a) the rate of tiller production falls below the theoretical rate, and this point, termed the 'departure point', can be described with reference to the number of emerged leaves on the main shoot. This change in rate was usually well defined and often no more tillers were produced. In some cases (e.g. fig. $2 b$, 'Sonja' sowing 1) tiller production continued after the departure point 


\section{TABLE 4}

Diagram to show the relationship between leaf emergence and tillering. The scheme illustrates potential tillering under ideal conditions assuming a phyllochron interval of 3 and similar rates of leaf emergence in all shoots (adapted from MASLE-MEYNARD \& SEBILLOTTE, 1981, table I).

Schéma montrant les synchronismes entre apparition des feuilles et apparition des talles. Ce schéma décrit le modèle de tallage potentiel $(=$ en conditions de nutrition optimales), si l'on retient un 'phyllochron interval' de trois et une vitesse d'apparition des feuilles constante entre tous les brins (adapté de MASLE-MEYNARD \& SEBILLOTTE, 1981, tabl. I).

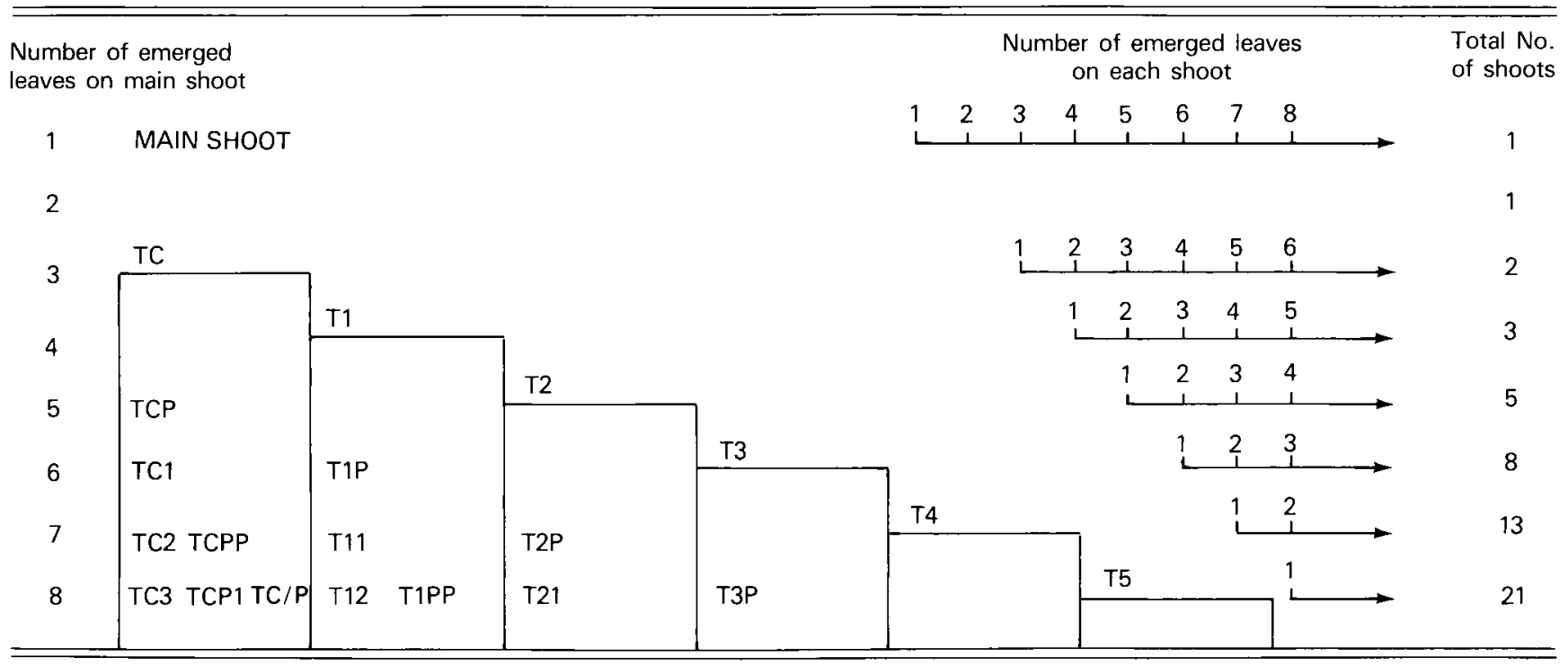

but at a much reduced rate. In the winter varieties the departure point tended to be at a lower leaf number in sowings 2 and 3 than in sowing 1 and at a higher leaf number again in sowing 4 (fig. $2 a$ ). It tended to be lower in spring varieties (fig. $2 b$ ). The departure point was estimated for each sowing date $\times$ variety treat-

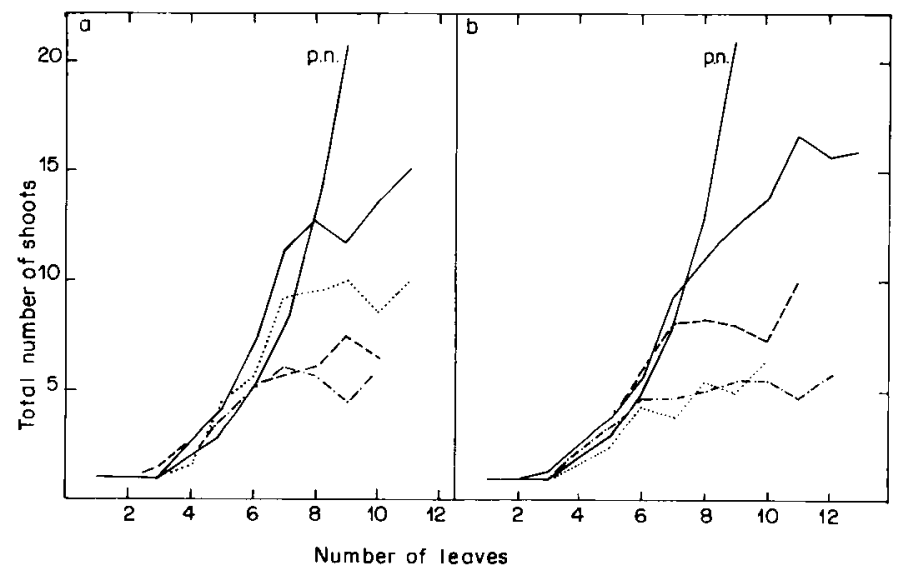

ment and the correlation between this and the total number of leaves initiated on the main shoot (KIRBY et al., 1985) and the number of the first internode to elongate on the main shoot was calculated. For wheat and barley in both seasons there were highly significant correlations between these characters (table 5).

Figure 2

Number of emerged leaves on the main shoot against total number of shoots. The thin line (p.n.) is the predicted number of shoots (see text). a) 1981/82 'Huntsman' winter wheat : - , sowing 1 ; ---, sowing 2 ; ....., sowing $3 ;$..., sowing 4. b) 1980/81:- 'Sonja' winter barley, sowing 1 ; -.-, 'Sonja', sowing 3 ; ...., 'Ark Royal' spring barley, sowing $1 ; \ldots$. , 'Ark Royal', sowing 3.

Nombre de feuilles sur le brin-maitre contre nombre total de brins (voir texte). La ligne fine (p.n.) représente le nombre prédit de brins.

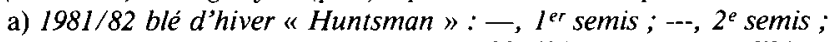
....-, $3^{e}$ semis ; ...., $4^{e}$ semis. b) 1980/81: —, orge d'hiver "Sonja », I ${ }^{\text {er }}$ semis; ---, "Sonja », $3^{e}$ semis, -...-, orge de printemps, «Ark Royal », I er semis ;...., « Ark Royal », $3^{e}$ semis.

TABLE 5

Correlations between number of leaves at the departure point and final number of leaves and number of the first elongated internode (see text). The correlations were calculated over both years for each species.

Corrélations entre nombre de feuilles du brin-maitre au 'departure point' (voir texte) nombre final de feuilles et numéro du premier entrenœud allongé (voir texte). Les corrélations ont été calculées au sein de chaque espèce, pour les 2 années confondues.

\begin{tabular}{|c|c|c|c|c|c|}
\hline & & & $r$ & d.f. & $\mathbf{P}$ \\
\hline $\begin{array}{l}\text { a) Number of leaves at the } \\
\text { departure point }\end{array}$ & $\begin{array}{l}\text { v. final number } \\
\text { of leaves }\end{array}$ & $\begin{array}{l}\text { Barley } \\
\text { Wheat }\end{array}$ & $\begin{array}{l}0.564 \\
0.699\end{array}$ & $\begin{array}{l}70 \\
62\end{array}$ & $\begin{array}{l}0.001 \\
0.001\end{array}$ \\
\hline $\begin{array}{l}\text { b) Number of leaves at the } \\
\text { departure point }\end{array}$ & $\begin{array}{l}\text { v. number of first } \\
\text { elongated internode }\end{array}$ & $\begin{array}{l}\text { Barley } \\
\text { Wheat }\end{array}$ & $\begin{array}{l}0.564 \\
0.735\end{array}$ & $\begin{array}{l}70 \\
62\end{array}$ & $\begin{array}{l}0.001 \\
0.001\end{array}$ \\
\hline $\begin{array}{l}\text { c) Final number } \\
\text { of leaves }\end{array}$ & $\begin{array}{l}\text { v. number of first } \\
\text { elongated internode }\end{array}$ & $\begin{array}{l}\text { Barley } \\
\text { Wheat }\end{array}$ & $\begin{array}{l}0.919 \\
0.915\end{array}$ & $\begin{array}{l}70 \\
62\end{array}$ & $\begin{array}{l}0.001 \\
0.001\end{array}$ \\
\hline
\end{tabular}




\section{DISCUSSION}

The results from this paper showed that there were differences in leaf emergence rate between the main shoot and tillers. This finding agrees with that of FLETCHER \& DALE (1977) who found that the rate of leaf emergence of $\mathrm{T} 1$ of 'Proctor' barley was less than $80 \%$ of the main shoot (cf. average of $84 \%$ for barley in this paper (from table 1)). Other workers (FRIEND, 1965; KIRBY \& RIGGS, 1978 ; MASLE-MEYNARD \& SEBILlOTTE, 1981 ; KLEPPER et al., 1982) have shown that in their experiments there were no differences in leaf emergence rate between main shoot and tillers. In the experiments reported in this paper and in those of FLETCHER \& DALE (1977) the lower rate of $\mathrm{T} 1$ and other primary tillers was not due to incipient senescence as suggested by KLEPPER et $a l$. (1982) as this tiller later produced ears. It is therefore not justified in all circumstances to assume that the leaves on the main shoot and tillers emerge at the same rate. The reasons for the variation are not clear. The experiments reviewed in this paragraph were done in a variety of environments and no one factor emerges as being primarily responsible for the variation. FLETCHER \& DALE (1977) suggests that relative differences may be genetic in origin but in the same variety the relation of the rate of the main shoot and tillers varies from experiment to experiment (e.g. spring barley variety 'Proctor' in FLETCHER \& DALE, 1977 and in KIRBY \& RIGGS, 1978).

When the phyllochron interval was estimated by regression method it was of shorter duration than estimates based on observation of number of leaves on the main shoot and the time of emergence of the tiller. This difference was observed by KLEPPER et al. (1982) who found the 'beginning point' occurred before tiller emergence, determined by direct observation. A possible reason for the difference may be seen in figure 2 of FLETCHER \& DALE (1977) who noted that the leaves of T1 and T2 showed a marked divergence from the linear trend, because the second leaf emerged very soon after the first.

FRIEND (1965) showed that low light and high temperature increased the leaf interval. At 2,500 foot candles $(27,000 \mathrm{lux}), 10^{\circ} \mathrm{C}$ the leaf interval was 2.2 ; at 1,000 foot candles $(10,800$ lux $), 30^{\circ} \mathrm{C}$ it was 5.2 . The phyllochron interval for primary tillers of 'Stephens' wheat determined by KLEPPER et al. (1982) varied from 1.7 to 4 over a range of sowing conditions. Values for field-grown plants given in that paper varied from 1.7 to 5.5. The phyllochron interval values for TC were higher than for the other tillers but otherwise no clear trends emerged in relation to season or type of growing conditions. MASLE-MEYNARD \& SEBILLOTTE (1981) found a phyllochron interval of 3 for 'Talent' winter wheat and used this in the construction of table 1 in their paper. KIRBY \& RIGGS (1978) found that the phyllochron interval for spring barley ranged from 1.8 to 3.1 ; the interval for TC was longer than for the other primary tillers and was longer for a secondary tiller (T1P) than for the primary tillers.

It appears on this evidence that there is variation in the phyllochron interval at tillering, the coleoptile and the secondary tiller (T1P) generally having a longer interval than primary tillers. However both KLEPPER

et al. (1982) and Masle-Meynard \& SebillotTe (1981) found that T1P emerged slightly before T3. Growth room experiments indicate that high temperature increased the phyllochron interval and these experiments show that later sowing also generally makes it longer (except TC, table 3). There is no clear evidence that there is any genotype or species difference in the duration.

To increase the rate of tillering or number of tillers by breeding methods it seems that selection for rate of leaf emergence and number of leaves is likely to be most effective. Variation is known to exist in this character (e.g. KIRBY et al., 1985 ; KIRBY \& RIGGS, 1978 ; SYME, 1974) and difference in leaf rate can substantially affect tillering rate (fig. 3 ).

There is little indication that there is useful genetic variation in the phyllochron interval for tillering. However, the range of genotypes examined for this character is small and if significant variation exists it would have considerable effect on tiller production (fig. 3).

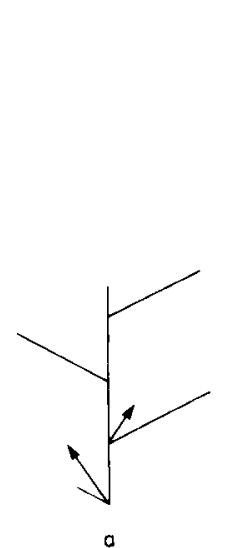

Figure 3

Diagram to show the effect of different rates of leaf emergence and phyllochron interval on tillering. Each diagram represents a plant grown for 50 days at $10{ }^{\circ} \mathrm{C}$. For clarity only the coleoptile and main shoot leaves are shown but number of leaves on the tillers is represented by their relative length. Rate of leaf emergence (leaves $/ 100^{\circ} \mathrm{Cd}$ ) and phyllochron interval, respectively, for each plant are : a) 1,3 ; b) 2,3 ; c) 1,2 .

Schéma montrant l'effet de taux d'apparition des feuilles et d'intervalles phyllochrones différents sur le tallage. Chaque schéma représente une plante croissant 50 jours à $10^{\circ} \mathrm{C}$. Pour raison de clarté, seuls le coléoptile et les feuilles du brin-maitre sont représentés, mais le nombre de feuilles sur les talles est indiqué par leur longueur relative. Le taux d'apparition des feuilles (feuilles/100 degrés jours) et l'intervalle phyllochrone pour chaque plante sont respectivement : a) 1,3 ; b) 2,3 ; c) 1,2 .

The cessation of tillering is known to be strongly affected by external factors. For example, DARWINKEL (1978) showed that the time of maximum number of tillers depended on the density of plants. ASPINALL (1961) was able to regulate duration of the tillering phase by modifying the timing of application and concentration of the culture solution. However in the experiments described in this paper the strength of correlations (a) and (b) shown in table 5 indicate that internal factors are also important. Under the conditions of this experiment tillering ceased at the elongation of the first internode which occurred when 
the shoot apex was at maximum number of primordia stage in barley or terminal spikelet stage in wheat and when rapid stem and ear growth began. Therefore there may be an increase in competition within the plant for resources such as carbon assimilate or nitrogen compounds. The number of the first internode to elongate was strongly correlated with final number of leaves on the main shoot (table 5, c). Number of leaves has a strong genetic component and thus selection for this leaf character may also be expected to influence maximum number of tillers per plant.

However, it is known that there are correlations between leaf rate and number of leaves and other agronomic characters such as ear size (KIRBY \& RIGGS, 1978) and selection for rate of leaf emergence may also affect the phyllochron interval. Further investigations of the relationship between number of leaves, leaf growth, rate of leaf emergence and tiller growth and emergence may clarify the implications of selecting for these leaf characters.
The close relationship between number of leaves and number of tillers that has been demonstrated in this and other papers may facilitate analysis of the progress of crop growth and the detection of stress due to nutrient shortage and other factors. It is possible to predict the potential number of tillers for any leaf number on the main shoot. These parameters can be linked for example in the Zadoks 'growth stage' system (ZADOks et al., 1974) which is widely used in agronomic practise. In this system sub-section 1 (1 1 , 12 , etc.) indicates the number of leaves on the main stem while sub-section $2(21,22$, etc.) measures the number of tillers. Thus if in monitoring the crop growth and development a deviation is detected from the expected tiller development, some stress may be indicated. Inspection of the tiller pattern and determination of the position of missing tillers may indicate when such stresses may have occurred.

Reçu le 19 janvier 1984. Accepté le 15 octobre 1984.

\section{REFERENCES}

Aspinall D., 1961. The control of tillering in the barley plant I. The pattern of tillering and its relation to nutrient supply. Aus. J. Biol. Sci., 14, 493-505.

Cannell R. Q., 1969. The tillering pattern in barley varieties. I. Production, survival and contribution to yield by component tillers. II. The effect of temperature, light intensity and daylength on the frequency of occurrence of the coleoptile node and second tillers. $J$. Agric. Sci., Camb., 72, 405-422 and 423-435.

Darwinkel A., 1978. Patterns of tillering and grain production of winter wheat at a wide range of plant densities. Neth. J. Agric. Sci., 26, 383-398.

Engledow F. L., Ramiah K., 1930. Investigations of yield in cereals. VII. A study of the development and yield in wheat based on varietal comparison. J. Agric. Sci., Camb., 20, 265-344.

Fletcher G. M., Dale J. E., 1977. A comparison of mainstem and tiller growth in barley : apical development and leaf unfolding rates. Ann. Bot., 41, 109-116.

Friend D. J. C., 1965. Tillering leaf production in wheat as affected by temperature and light intensity. Can. J. Bot., 43, 1063-1076.

Haun J. R., 1973. Visual quantification of wheat development. Agron. J., 65, 116-119.

Innes P., Blackwell R. D., Austin R. B., Ford M. A., 1981. The effects of selection for number of ears on the yield and water economy of winter wheat. J. Agric. Sci., Camb., 97, 523-532.
Kirby E. J. M., Appleyard M., 1981. Cereal Development Guide. NAC Cereal Unit, Stoneleigh, $80 \mathrm{p}$.

Kirby E. J. M., Appleyard M., Fellowes G., 1985. Effect of sowing date and variety on leaf emergence and number of leaves of barley in wheat. Agronomie, 5 (2), 117-126.

Kirby E. J. M., Riggs T. J., 1978. Developmental consequences of two-row and six-row ear type. 2. Shoot apex, leaf and tiller development. J. Agric. Sci., Camb., 91, 207-216.

Klepper B., Rickman R. W., Peterson C. M., 1982. Quantitative characterization of vegetative development in small cereal grains. Agron. J., 74, 789-792.

Masle-Meynard J., Sebillotte M., 1981. Etude de l'hétérogénéité d'un peuplement de blé d'hiver. I. Origine des différentes catégories d'individus du peuplement ; éléments de description de sa structure. Agronomie, 1 (3), 217-224.

Rawson H. M., 1971. Tillering patterns in wheat with special reference to the shoot at the coleoptile node. Aust. J. Biol. Sci., 24, 829841

Syme J. R., 1974. Leaf appearance rate and associated characters in some Mexican and Australian wheats. Aust. J. Agric. Res., 25, 1-7.

Zadoks J. C., Chang T. T., Konzak C. F., 1974. A decimal code for the growth stages of cereals. Weed Res., 14, 415-421. 